\title{
INTEGRATED ASSESSMENT OF IRRIGATION WATER QUALITY BASED ON HARRINGTON'S DESIRABILITY FUNCTION
}

\author{
Larissa VOITENKO $^{1^{*} \odot \quad \text { Andrii VOITENKO }}{ }^{2 \oplus}$ \\ ${ }^{1}$ National University of Life and Environmental Sciences, Agrobiological Faculty, Department of Analytical, Bioinorganic \& \\ Water Quality, Kiev, Ukraine \\ ${ }^{2}$ National Aviation University, Educational-Research Institute of Ecological Safety, Kiev, Ukraine \\ "Corresponding Author: larisa.nubip@gmail.com
}

\begin{abstract}
It was proposed the integrated approach to the irrigation water assessment as its quality index IWQI. This criteria is united the quantitative assessment of different risks such as soil sodicity, plant toxicity, biofilm formation in drippers of irrigation systems etc. It is proposed to combine agronomic, ecological and technological requirements to the irrigation water using a generalized Harrington's desirability function (HDF). Within the framework of this concept, it was developed the scales of particular HDF for physico-chemical indicators, SAR values, and the Stebler's irrigation coefficient. IWQI was determined for the assessment of water quality for irrigation purpose on the examples of 3 dug wells located on the Agronomic Experimental station of National University of Life and Environmental Sciences of Ukraine (Pshenichne village, Kiev region). It is shown that water quality varies considerably (from 56 till $85 \%$ ).
\end{abstract}

Keywords: Irrigation, Water Quality Index (IWQI), Harrington's Desirability Function, Physical-Chemical Parameters

Received: 27.11.2017 Accepted: 03.12.2017 Published: 20.12.2017

\section{INTRODUCTION}

Global climate change requires reviewing the approaches to irrigated agriculture using. In particular, irrigation is assessed as a mitigation factor potentially reduced the impacts of climate change on agriculture by about 40\% [1]. Therefore, the environmental and land reclamation assessment of natural waters should be comprehensive, taking into account the soilclimatic conditions of the irrigation zone, the physiological features of agricultural crops and the requirements of the functioning of the technical means of the irrigation system.

The concept of the generalized water quality assessment in the form of so-called Water Quality Index (WQI) has been proposed by R. Horton in 1965 [2]. During last decades this idea was significantly improved and expanded [3-6]. WQI modifications has been accepted as regional or state standards of complex water assessment in the Great Britain, USA, Canada, India, Poland. The comprehensive review of the WQI concepts, its application included classification, analysis of methodological collisions, applied computer software, and WQI using for monitoring and simulation of water resource quality dynamics for the sustainable development was made by Abassi and Abassi [7]. Simsek and Gunduz [8] proposed GIS-integrated irrigation water assessment in the form multi-parametric irrigation water index IWQ. Authors used the linear combination of the parameters determined the different kinds of irrigation risks for soils and plants and subdivided the water quality into three groups. Sutadian et al. [3] pointed on the methodological problems of WQI using as a water assessment technique: (i) there is no unified step-by-step strategy of WQI development; (ii) most WQIs are designed for a specific region or separated biocenosis (objects with an individual set of hydro-chemical, hydrological characteristics); (iii) random choice of parameters, their weighting factors, procedure of sub-indices generating, etc.

Agronomic, soil, environmental requirements to irrigation water quality and, as a result, the demand to irrigation projects are a subject of intensive discussions [9, 10]. Thus, agronomic criteria focus on indicators that should ensure the quantitative and qualitative composition of the 
crop and not cause soil degradation (salinity, sodicity, infiltration, gas disruption, oxidationreduction potential). To do this, it is necessary to monitor water temperature, the $\mathrm{pH}$, the electrical conductivity, the total mineralization, mineral matrix composition $\left(\mathrm{Na}^{+}, \mathrm{K}^{+}, \mathrm{Mg}^{2+}, \mathrm{Ca}^{2+}, \mathrm{HCO}_{3}^{-}+\right.$ $\mathrm{CO}_{3}^{2-}, \mathrm{Cl}^{-}, \mathrm{SO}_{4}^{2-}$ ), the nutrient elements contents $\left(\mathrm{NH}_{4}^{+}, \mathrm{NO}_{3}^{-}, \mathrm{NO}_{2}^{-}, \mathrm{PO}_{4}^{3-}, \mathrm{C}_{\text {org }}, \mathrm{P}_{\text {org }}\right)$, trace elements and toxicants $(\mathrm{B}, \mathrm{Cu}, \mathrm{Zn}, \mathrm{Mo}, \mathrm{F}, \mathrm{Co})$.

\section{MATERIALS AND METHODS}

\section{Water Sources}

Mainly, the rural areas in Ukraine are supplied of local water sources for human and animal consumption, and irrigation [11]. Three boreholes situated on the territory adjoining to the Agronomic Experimental station of National University of Life and Environmental Sciences of Ukraine (Pshenichnoe village, Kiev region) were determined for experimental assessment of its water quality for irrigation purposes:

Object \# 1 - 50 $05^{\prime} 45.8^{\prime \prime} \mathrm{N}, 30^{\circ} 12^{\prime} 22.4^{\prime \prime} \mathrm{E}$ (50.096043, 30.206210);

Object \# $2-50^{\circ} 05^{\prime} 43.2^{\prime \prime} \mathrm{N}, 30^{\circ} 12^{\prime} 25.9^{\prime \prime} \mathrm{E}$ (50.095322, 30.207190);

Object \# $3-50^{\circ} 05^{\prime} 30.2^{\prime \prime} \mathrm{N}, 30^{\circ} 12^{\prime} 29.8^{\prime \prime} \mathrm{E}$ (50.091724, 30.208282).

Sampling was done in September, 2017. Monitoring design was made due to the EPA recommendations [12].

\section{Chemical Analysis}

The water quality parameters were measured in the Measuring laboratory of surface, underground waters and wastes of Analytical and Bio-inorganic Chemistry \& Water Quality Department, which is the structural subdivision of Ukrainian Laboratory of Quality and Safety of AIS Products of National University of Life and Environmental Sciences of Ukraine (certificate of approval No TÜB Lab-01).

\section{RESULTS AND DISCUSSION}

It is proposed to combine agronomic, ecological and technological requirements to the irrigation water using a generalized Harrington's desirability function (HDF) [13]. On our opinion, this conception is very similar to the WQIs, but more flexible and may be adapted to any kind of water consumption/nature of water sources (surface, underground).

Within the framework of this concept, it was developed the scales of particular HDF $d_{i}$ for physico-chemical indicators, SAR values, and the Stebler's irrigation coefficient (Table 1).

In accordance with recognized procedures [9, 14] it was calculated SAR coefficient (Table 2) and Stebler's irrigation coefficient (Table 3).

Table 1. Scale for particular $\mathrm{d}_{\mathrm{i}}$ assessment

\begin{tabular}{|c|c|c|c|c|c|c|c|}
\hline \multirow[b]{2}{*}{$\mathrm{i}$} & \multirow[b]{2}{*}{ Parameters } & \multirow[b]{2}{*}{ Units } & \multicolumn{5}{|c|}{ Values of particular $d_{i}$} \\
\hline & & & $\begin{array}{l}1,00 \ldots 0,80 \\
\text { Very good }\end{array}$ & $\begin{array}{l}0,80 \ldots 0,63 \\
\text { Good }\end{array}$ & $\begin{array}{l}0,63 \ldots 0,37 \\
\text { Satisfactorily }\end{array}$ & $\begin{array}{l}0,37 \ldots 0,20 \\
\text { Badly }\end{array}$ & $\begin{array}{l}0,20 \ldots 0,00 \\
\text { Very badly }\end{array}$ \\
\hline 1 & Salinity & $\mathrm{mg} / \mathrm{L}$ & $320-480$ & $\begin{array}{l}481-1000 \\
150-319\end{array}$ & $\begin{array}{l}1001-3500 \\
100-149\end{array}$ & $\begin{array}{l}3501-5000 \\
80-99\end{array}$ & $\begin{array}{l}5001-10000 \\
0-79\end{array}$ \\
\hline 2 & Temperature & $\begin{array}{l}\text { Celsius } \\
\text { degree, } \\
{ }^{\circ} \mathrm{C}\end{array}$ & $21-16$ & $\begin{array}{l}12-15 \\
22-24\end{array}$ & $\begin{array}{l}9-11 \\
25-28\end{array}$ & $\begin{array}{l}7-9 \\
29-31\end{array}$ & $\begin{array}{l}0-8 \\
32-45\end{array}$ \\
\hline 3 & $\mathrm{pH}$ & $\mathrm{pH}$ units & $6,9-7,0$ & $\begin{array}{l}6,5-6,8 \\
7,1-7,5\end{array}$ & $\begin{array}{l}6,1-6,4 \\
7,6-8,5\end{array}$ & $\begin{array}{l}5,5-6,0 \\
8,6-9,0\end{array}$ & $\begin{array}{l}3,5-5,4 \\
9,1-11,0\end{array}$ \\
\hline 4 & Iron total & $\mathrm{mg} / \mathrm{L}$ & $0-0,05$ & $0,06-0,20$ & $0,21-1,00$ & $1,01-5,00$ & $5,01-90,000$ \\
\hline 5 & Turbidity & NTU & $0-5$ & $6-10$ & $11-50$ & $52-200$ & $201-5000$ \\
\hline 6 & SAR & - & $2,0-3,0$ & $\begin{array}{l}1,5-1,9 \\
3,1-6,0\end{array}$ & $\begin{array}{l}1,2-1,4 \\
6,1-12,0\end{array}$ & $\begin{array}{l}0,9-1,1 \\
12,1-20,0\end{array}$ & $\begin{array}{l}0,1-0,8 \\
20,0-40,0\end{array}$ \\
\hline 7 & $\begin{array}{l}\text { Stebler's irrigation } \\
\text { coefficient } K_{C}\end{array}$ & - & $25,0-18,0$ & $17,9-6,0$ & $5,9-4,0$ & $3,9-1,2$ & $1,1-0,2$ \\
\hline 8 & Boron & $\mathrm{mg} / \mathrm{L}$ & $0-0,4$ & $0,4-1,0$ & $1,1-2,0$ & $2,1-5,0$ & $5,0-30,0$ \\
\hline 9 & $\begin{array}{l}\text { Nitrogen nitrates, N- } \\
\mathrm{NO}_{3}\end{array}$ & $\mathrm{mg} / \mathrm{L}$ & $0-4$ & $5-15$ & $16-20$ & $21-30$ & $30-1000$ \\
\hline
\end{tabular}


Table 2. SAR calculation

\begin{tabular}{|c|c|c|c|c|c|c|c|c|c|c|c|c|}
\hline \multirow[b]{2}{*}{$\begin{array}{l}\# \\
\text { obj } \\
\text { ect }\end{array}$} & \multirow[b]{2}{*}{$\begin{array}{l}\text { Total } \\
\text { hardness } \\
(\mathrm{Ca}+\mathrm{Mg}) \text {, } \\
\mathrm{mmol} / \mathrm{L}\end{array}$} & \multicolumn{5}{|c|}{ Ionic composition, $\mathrm{mmol} / \mathrm{L}$} & \multirow[b]{2}{*}{$\begin{array}{c}\text { Salinit } \\
\mathrm{y}, \\
\mathrm{mg} / \mathrm{L}\end{array}$} & \multirow[b]{2}{*}{$\begin{array}{c}\mathrm{PK}_{2}- \\
\mathrm{PK}_{0}\end{array}$} & \multirow[b]{2}{*}{$\mathrm{P}(\mathrm{Ca}+\mathrm{Mg})$} & \multirow[b]{2}{*}{$\mathrm{P}_{\mathrm{Alk}}$} & \multirow[b]{2}{*}{$\mathrm{pH}_{\mathrm{c}}$} & \multirow[b]{2}{*}{ SAR } \\
\hline & & Z & $\dot{U}$ & ḋ & 柋 & 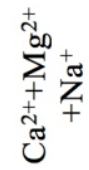 & & & & & & \\
\hline 1 & 29,30 & 1,56 & 9,35 & 1,52 & 19,99 & 30,86 & 2039 & 2,41 & 1,90 & 2,70 & 6,01 & 1,38 \\
\hline 2 & 12,37 & 2,03 & 3,22 & 0,18 & 11,00 & 14,40 & 917 & 2,31 & 2,20 & 1,95 & 6,46 & 2,40 \\
\hline 3 & 10,81 & 2,64 & 0,96 & 0,13 & 12,36 & 13,45 & 618 & 2,30 & 2,30 & 1,90 & 6,20 & 3,63 \\
\hline
\end{tabular}

Table 3. Stebler's irrigation coefficient calculation

\begin{tabular}{|c|c|c|c|c|c|c|}
\hline \multirow[t]{2}{*}{$\begin{array}{l}\# \\
\text { object }\end{array}$} & \multicolumn{3}{|c|}{ Ionic composition, $\mathrm{mmol} / \mathrm{L}$} & \multirow{2}{*}{$\begin{array}{l}\text { Relation between } \\
\mathrm{rNa}, \mathrm{rCl} \text {, and } \\
\mathrm{rSO}_{4}\end{array}$} & \multirow{2}{*}{$\begin{array}{l}\text { Formula of Stebler's irrigation } \\
\text { coefficient } K_{C}\end{array}$} & \multirow[t]{2}{*}{$\mathrm{K}_{\mathrm{C}}$} \\
\hline & $\mathrm{Na}^{+}$ & $\mathrm{Cl}^{-}$ & $\mathrm{SO}_{4}^{2-}$ & & & \\
\hline 1 & 1,56 & 9,35 & 1,52 & $r \mathrm{Na}<r \mathrm{Cl}$ & $288 / 5 r C l$ & 14,1 \\
\hline 2 & 2,03 & 3,22 & 0,18 & $r \mathrm{Na}<r \mathrm{Cl}$ & $288 / 5 r C l$ & 6,2 \\
\hline 3 & 2,64 & 0,96 & 0,13 & $\begin{array}{l}r \mathrm{Na}> \\
\left(r \mathrm{Cl}+r \mathrm{SO}_{4}\right)\end{array}$ & $288 /\left(10 \mathrm{r} N a-5 r C l-9 r \mathrm{SO}_{4}\right)$ & 17,9 \\
\hline
\end{tabular}

The procedure of mathematical transformation of measured natural parameters into $d_{i}[13]$, is made as for the parameters of so-called "one-side" limitation:

$\mathrm{d}_{\mathrm{i}}=\exp \left(-\exp \left(-\mathrm{x}_{\mathrm{i}}\right)\right), 0 \leq \mathrm{d}_{\mathrm{i}} \leq 1$,

where $\mathrm{x}_{\mathrm{i}}$ is coded value of $\mathrm{i}$-parameter $(\mathrm{i}=4,5,7,8,9$, Table 1$)$. These parameters are limiting as "less is better", or having "maximum permissible concentration" (MPC).

If executing parameter is limited as optimum field (having "two-side" limitation), it is transformed as:

$\mathrm{d}_{\mathrm{i}}=\exp \left[-\left(\mathrm{x}_{\mathrm{i}}\right)^{\mathrm{n}}\right]$, where $\mathrm{n}$ - any positive figure $(0<\mathrm{n}<\infty)(\mathrm{i}=1,2,3,6$, Table 1$)$.

This scale permits to transform any physical parameter in dimensionless entity expressed in psychophysical terms - "very good", "good", "satisfactorily", "badly", and "very badly".

So, the physical values of measured parameter are translated as the functions to a common scale $[0,1]$ (Table 4), combine them using the geometric mean (generalized HDF $\left.\mathrm{d}_{\Sigma}\right): \mathrm{d}_{\Sigma}=\sqrt[9]{\sum_{1}^{9} \mathrm{~d}_{\mathrm{i}}}$.

So, results of integrated assessment of water quality for irrigation purposes demonstrate the significant variability - from 56,61 \% - "satisfactorily" (object \#1) till 85,17 \% - "very good" (object \#3). It means that the underground waters have different degree of suitability. Analyzing particular $\mathrm{d}_{\mathrm{i}}$, it is clear that the critical parameter dramatically decreasing water quality of object \#1 is the nitrates pollution.

Table 4. Transformation of measured parameters into particular $\mathrm{d}_{\mathrm{i}}$ and generalized HDF $\mathrm{d}_{\Sigma}$

\begin{tabular}{|c|c|c|c|c|c|c|c|c|c|c|}
\hline \multirow[b]{2}{*}{ 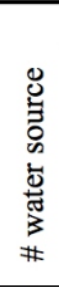 } & \multicolumn{9}{|c|}{ Measured values of water quality parameters } & \multirow{2}{*}{ 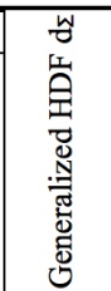 } \\
\hline & 害焗 & 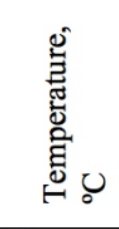 & 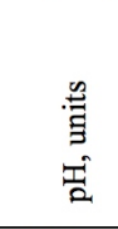 & 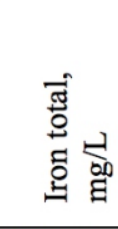 & 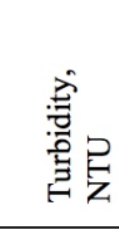 & 晃 & 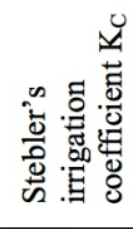 & 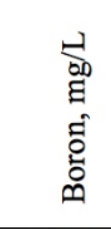 & 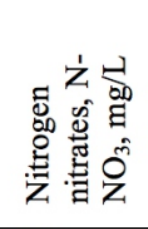 & \\
\hline 1 & 2039 & 21 & 7,25 & 0,049 & 1 & 1,38 & 14,1 & $<0,05$ & 35,3 & \\
\hline 2 & 917 & 20 & 7,30 & 0,075 & 1 & 2,40 & 6,2 & $<0,05$ & 3,8 & \\
\hline \multirow[t]{2}{*}{3} & 618 & 18 & 6,95 & 0,060 & 1 & 3,63 & 17,9 & $<0,05$ & 4,8 & \\
\hline & \multicolumn{9}{|c|}{ Values of particular $d_{i}$} & \\
\hline 1 & 0,3902 & 1,0000 & 0,7920 & 0,8010 & 0,9845 & 0,3805 & 0,7437 & 0,9998 & 0,1530 & 0,5661 \\
\hline 2 & 0,6480 & 0,9998 & 0,7837 & 0,7528 & 0,9845 & 0,9162 & 0,6506 & 0,9998 & 0,8137 & 0,8085 \\
\hline 3 & 0,7425 & 1,0000 & 0,9892 & 0,8000 & 0,9845 & 0,7480 & 0,8000 & 0,9998 & 0,8000 & 0,8517 \\
\hline
\end{tabular}




\section{CONCLUSION}

Analysis of the assessment principles of water quality for irrigation was done. It was shown that there is no standardized method because existing approaches evaluate the risks of different nature for plants, soils, or the water supply network. It was proposed to unite agronomic, environmental, and technician requirements to water quality in the form of the united Harrington's desirability function. In the framework of this conception it was developed the scales of the partial desirabilities for physical-chemical parameters, values of sodium-absorption ratio SAR, Stebler's irrigation coefficient. On the example of the three dug wells which are situated near Agronomic Research station (Pshenychne Village, Kyiv Oblast) use of the developed method was demonstrated. It has been established that water quality varied significantly within the study area. The quantitative assessment ranged from 56 till 85 $\%$ in terms on requirements of irrigation. The same methodology should be developed for water, which is used for foliar dressing, which often takes place simultaneously with irrigation.

\section{REFERENCES}

[1] Fischer, G., Tubiello, F.N., Velthuizen, H., and Wiberg, D.A. (2007) Climate change impacts on irrigation water requirements: Effects of mitigation, 1990-2080. Technological Forecasting and Social Change, 74, 10831107.

[2] Horton, R. K. (1965) An index number system for rating water quality. Journal of Water Pollution Control Federation, 37 (3), 300-306.

[3] Sutadian, A.D., Mutti, N., Yilmaz, A., Perera, B.J.C. (2016) Development of river water quality indices - a review. Environmental Monitoring Assessment, 188 (1), 58.

[4] Poonam, T., Tanushree, B., Sukalyan, C. (2015) Water quality indices - important tools for water quality assessment: a review. International Journal of Advances in Chemistry, 1 (1), 15-29.

[5] Tyagi, S., Sharma, B., Singh, P., Dobhal, R. (2013) Water quality assessment in terms of water quality index. American Journal of Water Resources, 1 (3), 34-38.

[6] Bikbulatov, E. S., Stepanova I. E. (2011) Harrington's desirability functions for assessing quality of natural waters, Russian Journal of General Chemistry, 81 (13), 26942704.
[7] Abbasi T., Abbasi S.A. (2012) Water quality indices. Elsevier, Oxford, $384 \mathrm{pp}$.

[8] Simsek, C., Gunduz, O. (2007) IWQ Index: A GIS-integrated technique to assess irrigation water quality. Environmental Monitoring and Assessment, 128 (1-3), 277-300.

[9] National Engineering Handbook. Irrigation Guide (1997). USDA, Washington, 652 pp.

[10] Frenken, K., Gillet, V. (2012) Irrigation water requirement and water withdrawal by country. FAO Aquastat Report, 263 pp.

[11] Kuznyetsov, V. (2006) Urban water resources management in Ukraine. In: Hlavinek P., Kukharchyk T., Marsalek J., Mahrikova I. (eds) Integrated Urban Water Resources Management. NATO Security through Science Series. Springer, Dordrecht, 69-78.

[12] Barselona, M.J., Gibb, J.P., Helfrich J.A., and Garske E.E. (1985). Practical Guide for Ground-Water Sampling: Illinois State Water Survey Department of Energy and Natural Resources Champaign, Illinois, 194.

[13] Voitenko, L., Kopilevich, V. (2016) Integrated water quality assessment for the animal watering in Velykosnytinske Education and Research Farm of National University of Life and Environmental Sciences of Ukraine, Biological Resources and Nature Management, 8 (3-4), 43-52.

[14] Silveira, L., Usunoff, E.J. Encyclopedia of Life Support Systems (EOLSS). Volume II. Groundwater. EOLSS Publishers, Oxford, $584 \mathrm{pp}$. 